\title{
Fundamentação da Psicologia em Aplicaçōes da Informática na Educação
}

Carla Beatris Valentini ${ }^{1}$ Léa da Cruz Făgundes ${ }^{2}$

\begin{abstract}
Resumo: Este artigo apresenta algumas raflexões sobre a aprendizagem e amblente virual envolvendo duas disciplinas dos cursos de psicologia pedagigia da Universidada de Caxias do Sul. As disciplinas abrangeram conhecimentos das novas tecrologias, bem como o estudo e reflexdo sobre as aplicaç5es da tecnalogia ra psicologia e na educacaso. Os encontros aconteceram de forma presencial e a distancia, tendo como base o site desenvolvido para o projeto. AQ mesmo tempo que se buscou conhecer as possibilidades deste ambiente parta a aprandizagem, tamben fol Imestigado a cooperacta e interaçăo dos alunos e professoras, buscendo desenvolwer trocas copperativas interdisciplinares. Alérm de contar com utr contexto de aprendizagem inowador. buscamos contemplar o pressuposto epistemológico piagetiano para o ctesenvolvimento das interaçes. Entre os resultados dessa investigaçá encontramos aspectos rglavantes quarito as

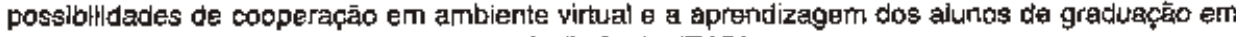
contextos construtvistas e de educaçào à distancia (EAD).
\end{abstract}

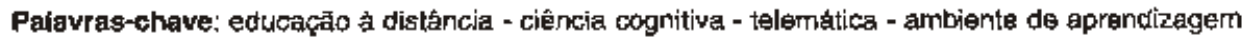
- cooperaça

Key-words: distance leaming - cognitive scignce - telematic - lęarring eminonment - cooperation

\section{Introduçāo}

A história da humaridade mostra-se como um continuum de batalhas $\theta$ superações. Desde os tempos mais remotos o homem vem enfrentando desafios e ameaças que exigem um esforço de mudança e adaptação, buscando assim invençōes e descobertas que marcam diferentemente cada época e o modo de viver humano.

O contexto atual nos evidencia o que talvez seja um dos maiores desafios enfrentados pela humanidade, o de viver numa era de constantes inovaçסes $\theta$ descobertas cientificas e tecnológicas. Năo obstante, embora o homem esteja imerso nessas rudanças parece năo ter comprendido totalmente o significado dessa nova realidade para a evoluçă do saber $\theta$ das relaçōes.

A rotina diária do homem contemporăneo pressupōe, cada vez mais, um acesso rápido ả informaçăo. O ingresso da tecnologia traz consigo transformaçóss e exigencias à sociedade que necessita estar atenta aos aspectos que ultrapassam a técnica $\theta$ a ciência em favor da compreensão e ação voltadas ao incremento das relaçōes de saber e cooperaçăo com o homem a com a natureza.

Conforme destaca Estrázulas (1997) é necessário "ter claro que se a tecnologia impul siona transtormaçōes culturais, năo as contém entretanto em sua totalidade. Isto signitica que serăo os indivíduos,(...) os legltimos responsáveis pela apropriação critica e emancipatória do uso de instrumentos digitais informacionais". Ser cooperativo e interativo está entre as habilidades essenciais para qualificar qualquer profissional que atuará no novo milênio.

A crescente demanda do uso da tecrologia tem chegado à educaçāo, no entanto, é fundamental uma reflexăo sobre seu uso: informática no ensino ov ensino de informática?

O meio educacional é um espaço privilegiado para apropriaçāo e construçāo do conhecimento. A escola e a universidade tèm o papel de instrumentalizar seus alunos e professores para pensar de forma criativa soluçōes para os problemas emergentes desta sociedade em constante transtomação. É necessário buscar a superaçáa deste descompasso existente entre a velocidade e a multiplicidade de mudanças tecnológica e sociais e o ritmo das mudanças na educaçāo, que permanece baseada no falar do professor e na reprodução escrita do aluno.

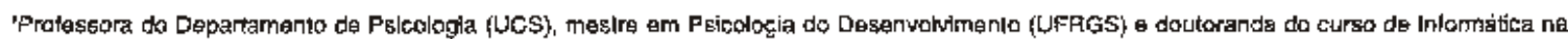

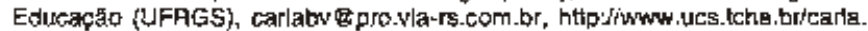

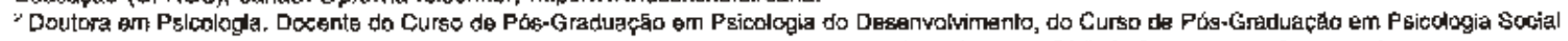

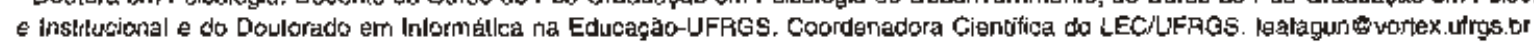


O modelo de transmissāo de conhecimento chega à universidade com toda a sua força e impregnaçāo. Durante anos de vida acadêmica o estudante s submetido a copiar, decorar e reproduzir iłfơmaçóes. A mudanca desse paradigme educacional se faz urgente, no entanto, a ruptura exige uma nova visäo de sujeito, de mundo e de conhecimento. Poderá a tecnologia contribuir para essa ruptura e a construçāo de um sujeito atuante, crftico e cooperativo? Como a universidade pode apoderar-se da tecrologia em favor da construçăo do saber e näo simplesmente submeter-se às imposiçōes técnicas da informatizaçāo?

O uso da informática e da educação à distancia se nāo romper com esses antigos paradigmas empiristas de ensino-aprendizagem será mais uma ferramenta para a reproutução de informaçōes e nảo de construçăo do saber por parte dos alunos e professores. De acordo com Fagundes \& Basso (1997) e Estrézulas (1997) e a interaçăo com o objeto de conjecimento e com oufros sujeitos, através de diferentes tjpos de interaçăo, que permite a construçăo de um saber partilhado e a busca de inovaçôes pedagógicas e profissionais.

A universidade como produtora do saber e com o compromisso de prestar serviços a humanidade atraves de pesquisas e dos profissionais que por sla passam, necessita estar á frente no enfrentamento desses novos desafios. A Infoera, conceituada por Zufo (1997), como a generalização das redes de computadores e das redes de comunicaçáo tomam a propagação de conhecimentos e novidades praticamente instantẩneas. A característica principal da Infoera é a constante mudaņ̧a em todas as áreas e a necessidade de constante adaptaçäo.

Diante deste cenário de transformaçbes e desafios quanto ao novo paradigma de conhecimento e relaçōes sociais os cientistas e profissionais das cièncias humanas nảo podem alienar-se. Nosso projeto envolve duas áreas imprescindiveis para uma nova atuação social e educacional: a psicologia e a pedagogia. Seus papéis näo săo simplesmente trazer dados e informaçoses do sua área, mas reconstruir-se e refazer-se a partir dos desafios da techologia. Se faz necessário romper com estruturas fixas para poder atuar como pensador, crítico e interventor dessa nova proposta de conhecimento e cooperação.

Visando criar um ambiente de desequilibraçăo das concepo̧óes tradicionaís de ensino-aprendizagem e ajudando o sujeito a construir uma cultura informatizada e de saber cooperativo o projeto destinou-se a trabalhar com duas disciplinas da área de ciências humanas, uma do curso de Psicologia e outra do curso de Pedagogia, respectivamente Psicologia e as Tecnologias da Infomaça e Informática Educativa.

\section{A Teoria de Jean Piaget}

Sabemos que somente a implementaçāo da techologia na educação não gárante uma real aprendizagem e desenvolvimento do aluno. Ao mesmo tempo que avançam estudos e propostas de novas ferramentas a softwares para a educaça, grupos de pesquisadores (Fagundes, 1992,1997; Famos, 1996; Estrázulas, 1997; Costa, 1995; Barros, 1994; Nevado,1996; Lévy, 1998b; Moraes, 1997; Valentini, 1995) preocupados em compreender a construçāo do conhecimento nesses ambientes de aprendizagem tecnologicos tern rompido com o paradigma tradicional de conhecimento.

Tendo como fundamentaçäo a psicolog̣ia e epistemologia genética de Piaget es pesqujsas realizadas pelo Laboratório de Estudos Cognitivos (LEC) da UFRGS seguem a concepçáo da informática como uma ferramenta para ajudar o sujeito a conhecer e intervir no mundo. O professor neste erifoque tem o papel de questionador, facilitador do processo de aprendizagem ou tomada de consciancia do sujeito.

A concepçăo de Piaget sobre inteligência remete a uma abordagem onde o deservolvimento do pensamento é um processo de autêntica construçăo. Para Piaget (1987), e inteligênçia é uma forma de adaptação. E uma continua construçāo criando fomas cada vez mais complexas e buscando uma equilibraçáo progressiva entre o organismo e o meio. A inteligēncia possui estruturas variáveis e funçōes irvariáveis, estas últimas possibilitam descrever o mecanismo de funcionamento do pensarnento em temos biológicos. As funçðes irvariéveis sāo chamadas por ele de invariantes funcionais da inteligência. Funcionais, porque estāo ernoividos no funcionamento da inteligéncia e invariantes, porque qualquer que seja o momento evolutivo, sempre havera assjmilacăo do meio as atividades do sujeito e acomodaçäo destas atividades às características impostas pelo objeto. As funçoes invariantes básicas são a organizaçäo e a adaptaçäo, esta última, com seu dois componentes inter-relacionados - assimilaçāo e acomodaçăo. "O organismo adapta-se construindo materialmente novas formas para inseri-las nas do universo, ao passo que a intefigència prolonga tal criaçäo construindo, mentalmente, as estruturas suscetiveis de aplicarem-se ao meio. "(Piaget, 1987, p.15-16). 
Piaget deixa claro que se refere a adaptaçāo no sentido de processo, distinta da adaptaçăo-estado. Acompanhando o processo percebe-se que é a "organismo que se transforma em funçăo do melo, e essa variação tem por efeito urn incremento do intercâmbio entre o meio e aquele, favorável à sua conservaçăo, isto

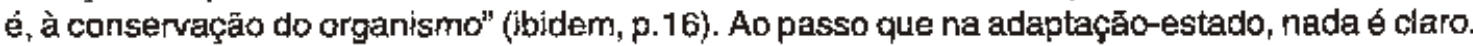

Toda vez que hâ uma incorporaçāo de dados à esquemas jê construidos oçorre a assimilação. Para assimilar um novo significado aos esquemas anteriores é necessário acomodar o proprio esquerra para permitir a incorporaçăo deste novo significado. Nisto constitui-se a acomodaçăo, na modificação dos esquemas para poder assimilar as várias situaçōes que se apresentam. Para a adaptaçąo ser considerada realizada precisa atingir um equilíbrio entre a acomodação e a assimilação. Não existe assimilaçäo sem acomodaçāo e viceversa, já que o meio desencadeia ajustamentos ativos tambén nāo existe adaptaçāo sem organizaçāo complementar dos dados incorporados a partir do que se retira das experiências.

Piaget explica o desenvolvimento e a formação do conhecimerto a partir de um processo central de equilibraçăo, que considera como sendo o problema central do desenvolvimento. O equilibrio cognitivo é entendido por Piaget como distinto de um equilíbrio mecârico (que se conserva sem modificaçăo) ou de urn equilibrio termodinámico (estado de repouso após a destruiçăo das estruturas). O equilibrio cognitivo é dinâmico, as trocas săo capazes de "construir e manter uma ordem funcional e estrutural num sistema aberto" (Prigogine em Plaget, 1976, p. 12). O equilibrio cognitivo supōe constantes trocas como o meio, porém preservando o sistema.

Os componentes de todo equilíbrio cognitivo săo os processos fundamentais da assimilação e da acomodaçáo. A teoria da equilibração possui dois postulados considerados básicos para sua elaboração: o primeiro, consiste em afirmar que a atividade do sujeito é motor da pesquisa, o qual pelo seu esquema de assimilaçăo busca incorporar elementos exteriores e compativeis; o segundo, é que o esquema de assimilaçāo precisa se acomodar aos elementos que assimila, ou seja, modificar-se em funçāo de suas particularidades, porém sem perder sua continuidade. A partir desse segundo postulado fica clara a necessidade de um equilibrio entre a assimilaçä̆o e a acomodaçăo.

Na teoria da equilibração a fonte de progresso no desenvolvimento está nos desequilíbrios, já que estes impelem o sujeito a ultrapassar seu estado atual e procurar avanços e novas direçōes. Quando esses elementos novos fazem com que as próximas assimilaçōes sejam diferentes das antoriores, levam a equilibrações majorantes, onde a novo equilibrio é superior ao anterior. Considerado do ponto de vista da equilibraçáa, os desequilibrios constifuem-se fonte de desenvolvimento, pois săo impulsionadores de novas equilibraçōes majorantes. Tomando essa perspectiva, 6 indispensável para o desenvolvimento este ciclo dialético de desequilibrios e equilibraçōes progressivas. O movimento progressivo das equilibraçōes 6 explicado por Piaget pelos conceitos de perturbaçōes, regulaçס̃es e compensaçóes.

"Săo estes desequil|brios que constituem a móvel da pesquisa, pois sem eles o conhecimento permaneceria estático (...) os desequilíbrios não representam senāo um papel de desencadeamento, pois que sua fecundidade se mede pela possibilidade de superálos (...). É evidente que a fonte real do progresso deve ser procurada na reequilibraçăo, (...) no sentido năo de um retorno a forma anterior de equilibrio, cuja insuficiència é responsável pelo conflito ao qual esta equilibraçăo provisónia chegou, mas de um melhoramento desta forma precedente" (Piaget, 1976, p. 19).

Quando o meio resiste è atividade do sujeito, sendo um obstáculo à assimilaçăo, ocorre a perturbaçảo. As perturbaçסes podem ou nīo levar a regulaçōes e estas, por sua vez, poden ou não ser compensatórias. A reaçăo do sujeito às perțrbaçöes se constituem nas regulações. A regulaçăo năo ocorre quando a perturbação leva à repetiçăo da ação, sem nenhuma mudança e o sujeito mesmo assim espera ser bem sucedido na sua açāo. Se não há regulaçōes tampouco há reequilibração. Para se produzir uma compensaçăa é necessário que a perturbação (obstáculo ou lacuna) leve à regulaçōes que intervèm sob a pressão dos sistemas de conjunto, isto é, quando as perturbaçôes conduzem a uma retroalimentação à cogniçāo. O processo intemo de regukaçōes e compensaçōes se dá através de mecanismas internos de assimilaçăo e acomodaçăa.

A reação do sujeito às perturbaçóes se constituem nas regulaçōes. A regulaçāo nāo ocorre quando a perturbação leva à repetição da açáo, sem nenhuma mudança e o sujeito mesmo assim espera ser bem sucedido na sua açăăo. Se nāo há regulaçōes tampouco hấ reequilibração. Para se produzir uma compensação é necessário que a pertubaçāo (obstáculo ou lacuna) leve à regulaçōes que intervém sob a pressão dos sistemas de conjunto, isto é, quando as perturbaçōes conduzem a uma retroalimentaçăo à cogniçăo. O processo interno de regulaçōes e compensaçðes se dá através de mecanismas internos de assimilaçāo e acomodaçāo. 
No momento em que surge um fáto novo que provoca a perturbaçăo trés tipos de condutas sāo observadas, estas se manifestam constantemente desde o sensório-motor até o pensamento operatónio-formal. A reequilibração e grau de equilibrio que se produz depende da conduta que é adotada na busca de compensaçăo.

A conduta inicial é chameda de Alfa $(\alpha)$ e a reaçăo frente a uma perturbaçāo consiste ne neutralizaçăo da perturbação, negligenciando-a ou afastando-a. As reaçōes de tipo a são parcialmente compensadoras, sendo que o equilibrio resultante é instável. Caracterza-se pela auséncia das retroaçōes e antecipaçŏes que seriam necessárias para integrar as perturbaçöes exteriores. Esta reação parte de estruturas restritas e fracas răo chegando assim a integraçōes novas ou compensaçöes.

A conduta Beta ( $\beta$ ) ́ a reaçắ seguinte e leva en conta a perturbaçăo, procurando um 'deslocamento de equitibrio' do sistema inicial. Consiste em integrar no sistema o elemento perturbador surgido do exterior. A compensação não mais procura anular a pertubação ou a rejeitar o elemento novo, para que ele năo intervenha no interior do conjunto já estruturado, mas em modificar o sisterna por "deslocamento de equilíbrio" ałé tornar assimilável o fato inesperado. O elemento perturbador incorpora-se a estrutura organizada, as novidades ele que provoca na estrutura asseguram a compensaçào, embora esta ainda seja parcial. A incorporaçăo desse novo elernento modifica o próprio esquema de assimilaçăo para acomodá-lo ao objeto e seguir sua orientaçāo. A conduta $b$ faz com que corra um deslocamento de equil lorio, mas com minimizaçăo das perdas (conservar o que é possivel do esquema de assimilaçāo) e múximo de ganhos (integrar a perturbação a titulo de variaçăo nova, interiorizada no esquema). As estratégias dessa conduta consistem em incorporar as perturbaçoes por um processo retroativo e antecipador produzinco variaçōes internas no sistema.

Por firm, a conduta Gama ( $\gamma$ ) "onde näo há tatores perturbadores, pois o sistema é ao mesmo tempo móvel e fechado e os dados exteriores năo mais constituem fontes de contradiçöes". ( Piaget, 1976, p.71.) Essa conduta consiste em antecipar as variaçoes possiveis, as quais sendo previslveis e dedutiveis, perdem a característica de perturbaçāo e vêm integrar-se nas transformaçóes virtuais do sistema. Essas condutas generalizam as antecipaçōes e retroaçōes sob a forma de composiçōes operatórias diretas e inversas, $\theta$ o que nos outros niveis era perturbaçăo é inteiramente assimilado como transformaçōes internas do sistema.

Essas condutas manifestam um progresso sistemático que, de forma geral, esclarece o progresso da equilibração dos sistemas cognitivos. Cada nivel a equilibração assenta-se sobre a compensaçāo, que se caracteriza por graus distintos de equilíbrio, sendo na primeira reaçăo o equilibrio muito instável e de campo restrito, ra segunda, os deslocamentos de equilíbrio se apresentam de múltiplas formas e na terceira reaçăo, o equilibrio é móvel, porém estável.

No momento em que esse proçesso dialético de reconstruçōes (equilibraçăo) năo mais envolve somente os objetos como tais, ou seja, as trocas do organismo com o meio, mas envolve conceitos, representaçöes imaginéticas, ocorre a abstração reflexiva (Ramozzi-Chiarotino, 1988). Seja no processo de equilibraçäo ou de abstraçăo reflexiva săo os desequilibrios que desencadeiam o processo e a possibilidade de superá-los é que determina a fecundidade destes. "A converșăo das negaçōes práticas em negaçōes conceihuais éa expressāo de um processo de construçáo ligado de perto ao jogo das regulaçóes e do qual ele se constitui um assunto inseparável: $\operatorname{\theta }$ a abstração reflexiva". (Piaget, t976, p. 38).

Plaget afima que a abstraçăo reflexiva intertere continuamente na formação das regulações de regulaçōes. O processo de abstraçäo reflexiva sustenta-se por dois momentos, inseparáveis: o reflexionamento que Piaget denomina refféchissement, ou seja, a projeçäo num nivel superior do que é retirado do plano inferior; e a ref́lexāo (réffexion) "como ato mental de reconstrução e reorganização no patamar superior do que foi transferido do interior "( Piaget, 1977, p. 303). A reconstrução no patamar superior é um estabelecimento de relaçōes entre as representaçōes ou novas formas e aquelas que já existiam com certa organizaçăo, ou seja, 6 um ato mental de reconstruçāo.

Podemos compreender que a evoluçăo, em temos de reconstruçăo, $\theta$ um ininterrupto processo em espiral, onde o reflexionamento dos conteúdos supōe a intervençāo da forma, de uma estrutura (reflexăo), e esses conteúdos quando transferidos a outro plano exigem a construçāo de novas formas.

Os estudos de Piaget tiveram como base condiçōes de interaçào baseadas em ambientes naturais e culturais. Com o advento da tecrologia outras dimensôes de interaçào säo acrescentadas, conforme Fagundes (1997), onde na estrutura de rede, o computador đeixa de ser o centro e passa a ser mais um elo da trama. "É na interaçăo cognitiva no seio de uma situaçăo que cada um, com reciprocidade, contribui para estabilizar, modificar ou reequilibrar a construção do conthecimento." (Fagundes, id., 1997) 
Com os novos ambientes de aprendizagem cooperativos surge a necessidade da reflexão sobre os laços sociais em torno do aprendizado recíproco. Lévy (1998b) define inteligẽncia coletiva não como um conceito exclusivamente cognitivo, mas antes de trabalhar em comum acordo. Segundo o autor é "uma inteligęncia distribuida por toda parte, incessantemente valorizada, coordenada em tempo real, que resulta em uma mobilizaçāo efetiva das competências".

\section{Como Piaget considera o social $\theta$ as trocas interindividuais na construçäo do conhecimento?}

As ciências sociais do século $X X$ têm dado mais importância ao social e as relaçōes do homem enquanto elemento funcional e necessário a preservaçăo do todo. A teơria psicogenética de Piaget aparece neste quadro afimando a existência de um sujeito ativo que é capaz de reconstruir o mundo externo $e$ as leis que o govemam. A existáncia do individuo não é mais entendida como um a priori. O sujeito passa a entender o mundo a partir de uma razăo comunicativa, um pensamento compartilhado, que toma possivel entender o ponto de vista do outro e elucidar methor o seu próprio pensamento.

A partir da psicogènese, Piaget reconstrói os estágios da formação da consciéncia individual, partindo do egocentrismo para chegar por descentraçðes sucessivas ao estágio da autonomia do "eu". O sujeito passa de uma noçăo difusa do "eu" para uma consciência do "eu" enquanto autor das açōes e reflexōes. A partir dessa consciéncia de si, aceita reformular o seu ponto de vista tendo como base uma argumentaçăo melhor e racionat. O pensamento torna-se comunicàvel num processo interativo, entre indivrduos, à base de uma linguagem comum e partithada. A linguagem permite que o pensamento seja expresso e reconhecido pelos outros, mas o desejo de comunicar-se só faz sentido quando existe alguérn capaz de ouvir, entender e trocar idéias. Essa diferenciação do ponto de vista do "eu" e dos "outros" so e possivel no grupo social.

Ramos (1996), apresenta a postura de Piaget com relaçáo a autonomia e o social, apontando que a autonomia nāo está relacionadia com isolamento. Pois para Piaget o surgimento do pensamento autônomo e Jógico operatório é paralelo ao surgimento da capacidade de estabelecer relaçóes cooperativas.

Nos "Estudos Sociológicos" Piaget tala da interdependéncia entre a sociogènese e a psicogênese. A criança não pode ser estudada sem lever em conta o social, pois uma criança o é en relaçăo a um gripo social e um meio deteminado. Entretanto, deixa claro que a interdepende̊ncia do social e do cognitivo näo implica em ignorar a construção individual do conhecimento. Todas as condutas supōe duas espécies de interaçāo que sāo indissociảveis uma da outra, a interação entre o sujeito $\mathrm{e}$ o objeto e a interação entre o sujeito e os outros sujeitos. Toda a teoria apresenta um aspecto dinâmico e dialético, não dando ênfase somente ao sujeito nem ao objeto, mas na interação que une e lança em direçăo às novas equilibrações.

Quando o social é tratado por Piaget o "eu "é substituido pelo "nós" e as interações são entendidas como condutas que se modificam umas as outras ou como formas de 'cooperaçăo'. $O$ desenvolvimento do egocentrismo as operaçōes lógicas é acompanhado de urra socialização das açöes, que vāo do egocentrismo a cooperaçăo. A descentraçăo do sujeito, considerando o ponto de vista do outro é fundamental na teoria psicogenetica.

Nos "Estudos Sociológicos" Piaget aponta ainda para a exiśtência de uma relaçāo complexa entre o desenvohimento operatório $\theta$ a socializaçăo, pois mesmo falando do social năo deixa de lado sua preocupaçáo epistemológica. Ao examinar as estruturas das interaçōes coletivas nos frostra como a socializaçāo do pensamento e o desenvolvimento operatório săo indissociáveis em forma e conteúdo, são duas faces da mesma moeda. Desta forma responde-nos a pergunta sabre se é a constituição dos agruparnentos de operaçōes concretas que permite a formaçăo da cooperação, ou vice-versa. O social e o individual são analisados a partir dos mesmos mecarismos. A interaçăo e a cooperação tem como forma comum de equillibrio o "agrupamento", como em toda sua teoria o que tem lugar privilegiado é o equilíbrio, e nāo existem dois modos de equilibrar as açōes, e a ação sobre o outro é inseparável da açăo sobre os objetos.

O desenvolvimento do egocentrismo às operaçסes lógicas 6 acompanhado de uma socializaçáo das açōes, que vão do egocentrismo à cooperaçăo. A descentraçāo do sujeito, considerando o ponto de vista do outro é fundamental na teoria psicogenética. Para Piaget "o conhecimento humano é essencialmente coletivo e a vida social constitui um dos falores essenciais da formaça e do crescimento dos conhecimentos..." (Piaget, id.,p.17). O conhecimento nāo é um produto isolado de um sujeito, para conhecer a interaçăo com o outro e parte integrante do processo. 


\section{Objetivos:}

- Aplicar os pressupostos da epistemologia genética piagetiana em ambientes de educaçăo virtual (ensino presencial e a distância).

- Propiciar aos estudantes a construçăo dos pressupostos epistemológicos piagetianos a partir das interaçōes em ambiente informatizado e das trocas cooperativas;

- Construir uma cultura informatizada a partir das vivencias e desafios em ambiente presencial e vitual;

- Possibilitar aos docentes construit e fazer uso de ambiente de troca e cooperação no planejamento e execuçāo das atividades.

\section{Cenărio de Implantação do Projeto}

O projeto econteceu nas disciplinas Pşicologia e Tecnologias da Informaçāo e Intormática Educativa dos cursos de Pścologia e Pedagogia da Universidade de Caxias do Sul. Este projeto está ligado a um projeto mais amplo denominado CMI - Cooperaçăo, Metodologia e Intervenções em Ambientes Virtueis de Aprendizagem que envolve também a área de ciêncies exatas. Um dos objetivos é integrar as duas áreas de conhecimento em projetos cooperativos comuns, atividades de educação à distância (sincronas e assincronas) com os dois grupos, além dos encontros em laboratório de cada disciplina. Neste artigo iremos apresentar alguns aspectos da disciplina Psicologia e Tecnologias da Informação.

\section{Estrutura do Ambiente de Aprendizagem}

\subsection{Ambiente virtual de aprendizagem}

O site desenvolvido para a disciplina Psicologia e as Tecnologias da Informaçāo segue uma estrutura de hiperdocurnento, buscando possibilitar a navegaçäo por qualquer um dos espaços de aprendizagem.

A disciplina tem momentos de cooperaçåo sincrona e atividades em conjunto, nem sempre a distăncia. Para facilitar as trocas cooperativas em tomo de um assunto, existe a opção Agenda, onde aparecem os desafios e propostas para os encontros.

\subsection{Contextos de aprendizagem:}

- Elos de aprendizagem

- Desafios: Linguagem Logo

- interesses: Interdisciplinares

- Portfólios coletivos

$$
\text { Psicologia }
$$

- Interfaces da Psicologia

- Subjetividade e Psicologia

- Portiólios coletivos

- Pólo Telemático

- Internet: WWW, The Palace, Netmeeting: e-mail, lista

- Portfólios coletivos

- Afetividade e Aprendizagem

- Tecnologia e aprendizagem

- Epistemologia genética de Jean Piaget

- Método clínico

- Portfólios coletivos

- Projetos

- Psicologia

- Pedagogia

- Interdisciplinar

- Portfólios coletivos

\section{- Biblloteca Virtual}




\section{- Alunos (web páginas dos alunos) \\ - Portfólios (porttólios individuais)}

- Agenda (cronogramá de encontros e atividades)

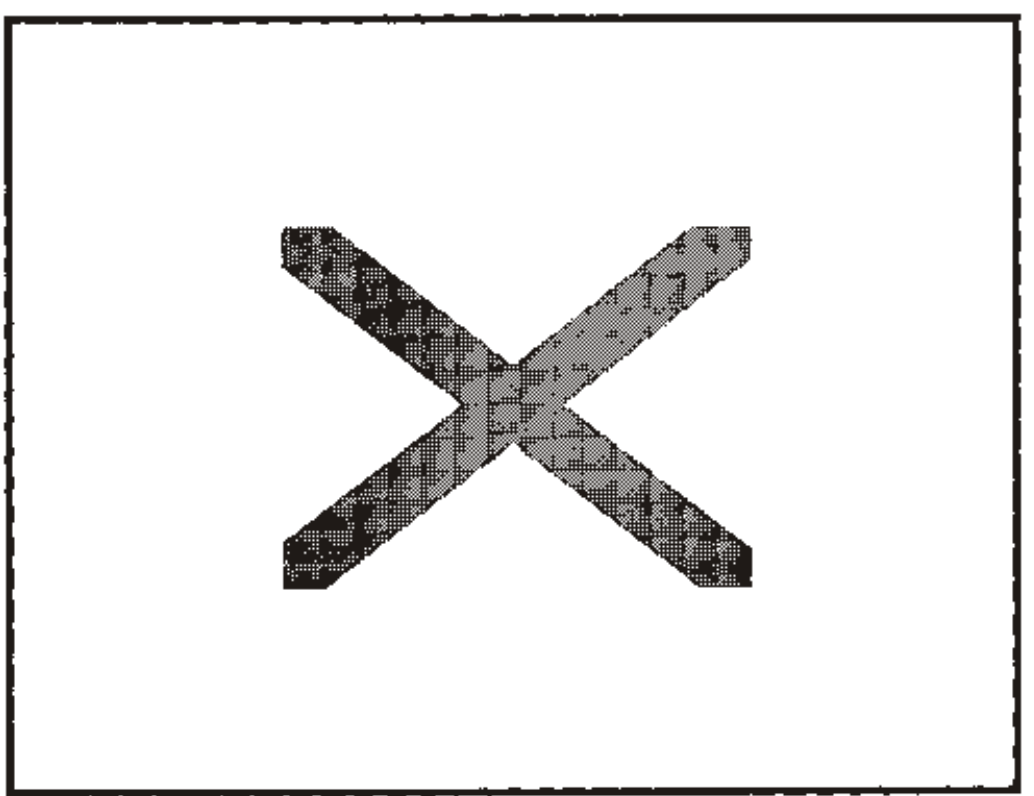

Figura 1 - Tela inicial

\section{Análise de alguns tópicos do contexto de aprendizagem}

A epistemologia genética piagetiana e os estudos sociológicos serviram de apoio para a construçăo do ambiente virtual de aprendizagem e das propostas de interaçäo que sāo articuladas através do mesmo. $\dot{E}$ importante deixar claro que $20 \%$ dos encontros se realizaram a distäncia, o restante aconteceu no laboratório de informática. No entanto, o șite da disciplina, com o contexto de aprendizagern foi o pano de fundo para as interaçóes. Podemos destacar alguns pontos da teoria que apoiam a proposta:

A teoria da equilibraçăo possui dois postulados considerados bésicos para sua elaboraçăo: o primeiro, consiste em afirmar que a atividade do sujeito é motor da pesqulsa, o qual pelo seu esquema de assimilação busca incorporar elementos exteriores e compativeis; o segundo, é que o esquema de assimilação precisa se acomodar aos elementos que assimila, ou seja, modificar-se em funçāo de suas panticularidades, porém sem perder sua continuidade.

Considerando o exposto acima as propostas de aprendizagem estavam centradas na atividade do sujeito, ou seja, na interação do sujeito com o objeto de conhecimento. Neste caso o objeto de conhecimento é entendido como o ambiente informatizado, os recursos da Internet, os textos e sites, os seus parceiros de turma e os colegas de turma da Pedagogia que interagiram com o grupo de forma sincrona (The Palace) e assíncrona (correlo eletrônico e formulários).

Essa ênfase na atividade do sujejto nem sempre é fácil de ser incorporada ao ambiente universitário. Em geral a concepção de que o professor traz os conteúdos que devem ser "passados" ao aluno e este deve assimilá-los da melhor forma ainda continua presente. Assim, com o decorrer dos trabalhos foi possivel constatar como, aos poucos, os alunos foram deixando de lado uma postura de dependência do professor para uma crescente autonomia. Em momentos de avaliação dos trabalhos os alunos afirmavam que nestes encontros eles estavam constantemente trabahando, o que era muito diferente das outras disciplinas do curso, no entanto consideraram ser "mais envolvente aprender desta forma". 
A visào de Plaget com relação a autonomia e o social, aponta que a autonomia não está relacionada com isolamento. Pois para Plageto surgimento do pensamento autónomo e lógico operatorio é paralelo ao surginento da capacidade de estabelecer relaçóes cooperativas.

Constatamos que, o embora os alunos de graduaçăo devam estar no nível lógico formal, o estabelecimento de relaçōes cooperativas näo acontece facilmente. É possivel perceber como as relaçōes de aprendizagem num ambiente de ensino fomal levam mais tacilmente a uma relaçấo de conformismo $\theta$ heteronomla, devido ao respeito unilateral e ao individualismo. Não é difícil de perceber o porquê, pois um aluno nảo passa impurne por anos de vida escolar. Destarte, abrir a possibilidade de cooperar com o outro e ser autônomo, requer mais do que simplesmente permitir e dar a oportunidade. Em nossa sociedade a discussäo e o canfronto de idélas, ao contrário de ser entendido como uma forma de construir um conhecimento mais elaborado e propiciar a reflexäo dos interocutores, é visto como uma disputa pessoal, gerandio muitas vezes atritos. Observamos que em muitas propostas de interaçăo os alunos fazjam suas contribuiçōes num nivel superficial, evitando questionar $o$ outro, propor diferentes possibilidades ou até mesmo expor suas dúvidas.

"Na ordem da inteligência, a cooperaçăo significa a discussäo dinigida objetivamente (de onde a discussão interiorizada que \& a deliberação ou refiexāo), a colaboração no trabalho, a troca de idéjas, o controle mütuo (tonto de necessidade de verificação e dernonstração) etc. Claro, pois, que a cooperaçăo é o ponto de partida de uma serie de atitudes importantes para a constitução e o desenvolvimento da lógica.... ". (Piaget, 1967:209).

A troca cooperativa, neste ambiente de aprendizagen, teve seu espaço privilegiado e foi ocorrendo mais constante e profundamente a partir do envolvimento dos alunos com os temas estudados e da compreensão da proposta. Vernos assim que o caminho da autonomia e da cooperação se faz pela construçăo do sujeito, a partir de suas vivências e das perturbaçōes.

A descentração do sujeito, consideranda o ponto de vista do outro e fundamental na teoria psicogenética.

Neste contexto observamos a possibilidade de descentração em diferentes momentos, um desses é quando os alunos interagiam com os colegas usando os recursos de comunicaçãa síncrona (The Palace). Existia a necessidade de fazer-se entender, colocando-se no lugar do outro, verificando assim se sua comuricação escrita e suas idéias realmente transmitiam o que era a intençäo. Isso aconteceu não somente nas interaçōes síncronas, mas também nas interaçōes assíncronas (formulấrios). Muitas vezes essas interaçōos levaram a perturbaçōes, ocasionando nos sujeitos diferentes condutas (alfa, beta e gama).

"E na interaça cognitiva no seio de uma situação que cada um, com reciprocidade, contribui para estabilizar, modificar ou reequilibrar a construçäo do conhecimento."(Fagundes, id., 1997)

Ao contrário de outros ambientes de aprendizagem, neste contexto o conhecimento foi uma construçäo coletiva do grupo. No decorrer do semestre os alunos produziram conhecimento interagindo. Os portfólios coletivos foram o espaço do aprender, onde esse aprender mais do que interagir com a máquina foi produzir conhecimento. A um més do final do semestre as contribuiçōes dos alunos em porttólios coletivos, já ultrapassavam 80 páginas.

Estamos vendo neste ambiente como o "conhece-te a ti mesmo" vai se tornando um "aprendamos a nos conhecer para pensar juntos" $e$ o "penso, logo existo" em umn "formamos uma inteligêncía coletiva, logo existimos eminentemente como comunidade" (Lévy , 1998). Esse novo espaço do saber coletivo näo pretende ser um amälgama de inteligências individuais, mas um somar, compartilhar, diferenciar e reconstruir singularidades.

\section{Comentários finais}

Essa experiencia faz parte do projeto LaVia (Laboratorio de Ambientes Virtuais de Aprendizagem) da Universidade de Caxias do Sul. A partir das experiências realizadas, análises e avaliaçōes estaremos fazendo uso destes dados como base para outras disciplinas, cursos e capacitação de professores da universidade. 


\section{Referências Bibbliográficas}

BARROS, L.(1994) Suporte a Ambientes Distrlbuidos para a Aprendizagen Cooperativa. Tese de Doutorado. COPPE/ UFRJ.

COSTA, A. R. F. (1995) Estudo dias interaçōes Interlndividuais em ambientes de rede telemática. Dissertaça de mestrado. Universidade Federal do Rio Grande do Sul, Porto Alegre.

ESTRÁŻULAS, M.B. P. (1997) Interaçä́o e sócio-cogniça na Intenet: A Teorla de Desenvolvimento sólo-cognitivo de Jean Plaget no Estudo das Trocas entre Crianças na Escola e Fora da Eecola. Dissertaçå de mestrado. Uniwersidade Federal do Rio Grande do Sul, Porto Alegre.

FAGUNDES, L. C.; Axt, M. (1992/ Comunicaçăo Via Rede Telemática: a Conatruçăo de um Saber Partilhado com vlstas a Mudanças na Prática Educativa.Letras de Hoje, 27 (4).

. L. C. \& Basso, M. V. (1997) Informática Educativa e Comunidades de Aprendizagem. Identidade Social e a Construça do Conhecimento. Porto Alegre: SMED.

_.... L. C. (1997) A Inteligência Coletiva - A Inteligênela Distribuída. Porto Alegre: Artes Medicas. Revišsta Patio, Ano 1, No 1, p. 14-17, Majolulho.

LEVY, P (1995) As techologilas da inteligência - 0 futuro do pensamento na era da informática. Rio de Janeiro: Editora 34.

P. (1998a) A Máquina Universo: criaçăo, cogniçäo e cultura infortiática. Porto Alegre: ArtMad.

. P. (1998b) A Intellgencla Coletiva: por uma antropologia do ciberespaço. Sāo Paulo: Ediçós Loyola.

PIAGET, J. (1973) Estudos Sociológicos. Rio de Janeiro: Companhia Editora Forense.

., J. (1976) A Equlllbraçä́ das Estruturas Cognitivas. Rio de Janeiro: Zahar Editores.

J. (1987) O Nascimento da Inteligência na Criança. 4a.ed. Rio de Janeiro: Editora Guanabara.

MORAES, M. C. (1997) O Paradigma Educacional Emergente. Campinas: Papirtis.

RAMOS, E. M. F. Análise ergonómica do sistema hiperNet buscando o aprendizado da cooperaça e da autonomia. Tese em Engenharia de Produção da UFSC, novembro 1996.

VALENTINI, C. B. (1995) A apropriaçáo da leítura e escrifta e os mecanismos cognitivos de sufeltos surdos na interaçăo em rede telemátlca. Dissertaçắo de mestrado. Universidade Federal do Rio Grande do Sul.

ZUFFO, J.A (1997) A Intoera: O Imenso desafio do futuro. Sto Paulo: Editora Saber Lida. 